УДК 340.2

DOI https://doi.org/10.32849/2663-5313/2019.6.34

\title{
Катерина Головко,
}

канд. юрид. наук,

здобувач кафедри конститучійного права та порівняльного правознавства

Ужгородського начіонального університету

\section{СИСТЕМАТИЗАЦІЯ МУНІЦИПАЛЬНОГО ЗАКОНОДАВСТВА УКРАЇНИ: ПРОБЛЕМИ ТА ПЕРСПЕКТИВИ}

У статті сформульовано, що систематизація муніципального законодавства України - це форма його вдосконалення, яка може мати нормотворчий або ненормотворчий характер. Нормотворчий характер притаманний консолідації та кодифікації муніципального законодавства України, а ненормотворчий характер - інкорпорації муніципального законодавства Украйни. На підставі аналізу муніципального законодавства України було сформульовано висновок, що його систематизачія здійснюється по відношенню до: а) положень начіональних нормативно-правових актів (Конституиії, законів України та підзаконних актів) - шляхом застосування інкорпорачії, консолідащії та кодифікаиї; б) положень міжнародних договорів, згода на обов'язковість яких надана Парламентом, шляхом застосування інкорпорачії. Аргументовано недоцільність застосування для систематизаціі муніципального законодавства Украӥни таких ї форм, як облік та звід законів.

Ключові слова: муніципальне законодавство, систематизація, систематизація муніципального законодавства, кодифікація, консолідація, інкорпорація.

Постановка проблеми. Автор цієї статті протягом багатьох років досліджує питання систематизації муніципального законодавства України, викладаючи результати своєї наукової діяльності у статтях у фахових виданнях. Як правило, кожна стаття присвячена окремій проблемі, а тому актуальним є узагальнення авторських висновків та пропозицій в межах однієї статті. У зв'язку 3 цим дана публікація матиме концентрований зміст, що з огляду на наявність обмежень до обсягу статей $є$ вимушеним компромісом.

Аналіз досліджень. Муніципальне законодавство є доволі дослідженою галуззю національного законодавства, але монографічні дослідження його систематизації поки що відсутні. Сплеск інтересу до систематизації муніципального законодавства України спостерігався на початку $2000-x$ років у зв'язку з розробкою та обговоренням Проекту Кодексу законів про місцеве самоврядування (Муніципального кодексу, дивись, наприклад, [1]), однак публікації з цього питання були представлені переважно газетними статтями, інтерв'ю фахівців, статтями у фахових виданнях. Що ж до інкорпорації та консолідації муніципального законодавства України зокрема та до його систематизації у цілому, то їх дослідженню поки що не приділялося достатньої уваги; існують лише поодинокі напрацювання у цій сфері щодо окремих інститутів (дивись, наприклад,
[2; 3]). А отже, такі праці є актуальними та необхідними для подальшого удосконалення муніципального законодавства України. Слід зазначити, що автор цієї статті протягом доволі тривалого часу працює у цьому напрямі (дивись, наприклад, [4-6]).

Мета статті - проаналізувати потенціал різних форм систематизації законодавства з метою їх застосування для подальшого удосконалення муніципального законодавства України.

Виклад основного матеріалу дослідження. Галузь муніципального законодавства України тісно пов'язана 3 однойменною галуззю права. Муніципальне право України - це сукупність правових норм, що регулюють суспільні відносини, пов'язані з місцевим самоврядуванням, у тому числі з прямою демократією на місцевому рівні, створенням та функціонуванням органів місцевого самоврядування в межах власних та делегованих повноважень. Муніципальне право України нині слід розглядати як комплексну галузь національної системи права. Деякі з їі джерел, однак не усі, охоплюються галуззю муніципального законодавства України, яка також має комплексний характер.

3 точки зору аналізу систематизації муніципального законодавства України навряд чи правильним буде застосовувати поняття «законодавство»у вузькому значенні та 
обмежитись лише класифікацією законів України, які регламентують суспільні відносини, пов'язані з місцевим самоврядуванням. Досліджуючи систематизацію муніципального законодавства України, доцільно також приділити увагу нормативно-правовим актам органів та посадових осіб місцевого самоврядування та іншим документам. Застосування для цього поняття «законодавство» у широкому розумінні, тобто не тільки як сукупності законів України, ставить питання визначення кола тих нормативноправових актів, які будуть охоплюватись цим поняттям.

Для дослідження питань систематизації муніципального законодавства України запропоновано визначити муніципальне законодавство України як систему, до якої входять Конституція, міжнародні договори, згода на обов'язковість яких надана Парламентом, закони України та підзаконні нормативно-правові акти, що регулюють суспільні відносини, пов'язані з місцевим самоврядуванням, у тому числі з прямою демократією на місцевому рівні, створенням та функціонуванням органів місцевого самоврядування в межах власних та делегованих повноважень

У процесі багаторічних досліджень систематизації муніципального законодавства України сформульовано та запропоновано для подальшого наукового дискурсу дефініцію цього поняття. Систематизація муніципального законодавства України - це приведення до структурної та логічної впорядкованості положень національних нормативно-правових актів (Конституції, законів України та підзаконних актів) та міжнародних договорів, згода на обов'язковість яких надана Парламентом, що регулюють суспільні відносини, пов'язані з місцевим самоврядуванням.

Приведення законодавства до структурної впорядкованості полягає в укрупненні нормативно-правових актів, які включено до муніципального законодавства України, а також у розташуванні документів у хронологічній, алфавітній, предметній послідовності. Розташування документів у певній послідовності може бути застосовано і до тих міжнародних договорів, які запропоновано включити до муніципального законодавства України. Виявлено, що приведення законодавства до логічної впорядкованості полягає у виключенні з текстів нормативно-правових актів застарілих норм та норм, які визнані Конституційним Судом України такими, що не відповідають Конституції України, заповненні прогалин, вирішенні колізій.

Досліджуючи систематизацію муніципального законодавства України, необхідно взяти до уваги, що воно вже пройшло період свого формування та становлення. Відповідно, теза про відсутність необхідності його систематизації внаслідок проведення «революційних» перетворень була актуальною приблизно протягом першого десятиріччя після проголошення незалежності країни, але не зараз, коли відбувається аж ніяк не формування та становлення, а вдосконалення муніципального законодавства України.

Необхідність систематизації муніципального законодавства України зумовлена потребами:

- ревізії актів муніципального законодавства України відповідно до принципів поточного етапу муніципальної реформи (децентралізації публічної влади, субсидіарності у сфері надання послуг тощо);

- ліквідації як прогалин (наприклад, у частині загальнодержавної регламентації організації та проведення місцевих референдумів), так і суперечностей у муніципальному законодавстві (наприклад, у частині того, чи є іноземні громадяни та особи без громадянства членами територіальних громад сіл, селищ, міст, чи ні);

- полегшення застосування актів муніципального законодавства фахівцями та пересічними членами територіальних громад; підвищення рівня правосвідомості та активізації правового просвітництва членів територіальних громад.

Також деякі форми систематизації законодавства можуть слугувати засобом активізації правотворчості у муніципальній сфері - це кодифікація муніципального законодавства України та консолідація муніципального законодавства України напряму та опосередковано - інкорпорація муніципального законодавства України.

Наступне сформульоване у процесі дослідження систематизації муніципального законодавства України узагальнення полягає в тому, що наразі їі стан не є задовільним. Виявлено, що кодифікований характер мають лише поодинокі акти, що містять норми муніципального законодавства, а саме:

- Конституція України;

- Закон «Про місцеве самоврядування в Україні» (вперше в українській юридичній літературі доведено, що цей закон має кодифікований характер, з посиланням на змістові характеристики та кількісні показники);

- деякі статути територіальних громад (інша частина статутів територіальних громад мають характер консолідованих нормативно-правових актів).

Що ж до такої форми систематизації муніципального законодавства, як його інкорпорація, то по відношенню до загально- 
державних нормативних актів про місцеве самоврядування та до актів органів місцевого самоврядування вона все частіше та частіше застосовується в електронній формі - шляхом їх узагальнення в межах електронної бази даних з контекстним пошуком.

На підставі цього констатовано, що наразі галузь муніципального законодавства України не має свого «однойменного» кодексу, хоча спроби його прийняття були. Системоутворюючим нормативно-правовим актом муніципального законодавства є Закон від 21 травня 1997 р. «Про місцеве самоврядування в Україні».

Слід зазначити, що низький рівень систематизації муніципального законодавства України зумовлюється браком відповідної політичної волі. Висновок аргументовано за підсумком аналізу текстів концептуальних документів про реформу місцевого самоврядування, які приймались протягом періоду існування України як незалежної держави центральними органами державної влади, до яких належать:

- Концепція адміністративної реформи, затверджена Указом Президента України від 22 липня 1998 р.;

- Концепція державної регіональної політики, затверджена Указом Президента України від 25 травня 2001 р.;

- Концепція щодо внесення змін до Законів України «Про місцеве самоврядування в Україні» та «Про місцеві державні адміністрації» 2001 р., схвалена Розпорядженням Кабінету Міністрів України від 1 березня 2001 р.;

- Концепція реформи місцевого самоврядування, схвалена Розпорядженням Кабінету Міністрів України від 29 липня 2009 р. (нині втратила чинність);

- Концепція реформування місцевого самоврядування та територіальної організації влади в Україні, схвалена Розпорядженням Кабінету Міністрів України від 1 квітня $2014 \mathrm{p}$.

У кожному з цих концептуальних документів приділено значну увагу подальшому удосконаленню муніципального законодавства, насамперед Закону «Про місцеве самоврядування в Україні» у цілому, але у жодному з них не йдеться про систематизацію муніципального законодавства України зокрема. Про систематизацію законодавства згадується лише у Концепції адміністративної реформи 1998 р., однак йдеться про адміністративне законодавство; пропозиції щодо його систематизації сформульовано хоча й стисло, але не поверхнево.

Виявлено, що здійснення систематизації муніципального законодавства України значно утруднюється тим, що у галузі муніципального законодавства досі немає уніфікованого доктринального підходу до нормотворчості в частині застосування однієї 3 теорій про природу місцевого самоврядування: громадської, державницької або теорії муніципального дуалізму. На підставі цього сформульовано пропозиції:

- послідовно дотримуватися у процесі здійснення систематизації муніципального законодавства однієї теорії місцевого самоврядування, що сприятиме подальшому вдосконаленню муніципального законодавства України у напрямі його доктринальної єдності;

- у здійсненні систематизації муніципального законодавства України дотримуватись теорії муніципального дуалізму.

Дослідження систематизації муніципального законодавства України було б неповним без аналізу їі форм. Застосування інкорпорації, консолідації та кодифікації для систематизації муніципального законодавства України не викликає заперечень. А ось застосування менш традиційних форм систематизації законодавства по відношенню до муніципального законодавства викликає певні зауваження. Так, облік не має перспектив застосування як одна з форм систематизації муніципального законодавства України 3 огляду на те, що:

- як форма систематизації законодавства облік поки що не отримав визнання більшості вчених, які досліджують питання систематизації;

- облік у муніципальному законодавстві не має таких особливостей, які відрізняли б його від обліку в інших галузях законодавства.

Запропоновано аналізувати облік в рамках дослідження інкорпорації муніципального законодавства України.

Щодо такої не дуже поширеної форми систематизації законодавства, як звід законів, визначено, що вона не має перспектив застосування як одна з форм систематизації муніципального законодавства України 3 огляду на те, що кількість законів, які регламентують відповідні суспільні відносини, в Україні є доволі невеликою (а саме, це Закони «Про місцеве самоврядування в Україні» від 21 травня 1997 р., «Про місцеві вибори» від 1 липня 2015 р., «Про добровільне об'єднання територіальних громад» від 5 лютого 2015 р., «Про співробітництво територіальних громад» від 17 червня 2014 р., «Про органи самоорганізації населення» від 11 липня 2001 р., «Про статус депутатів місцевих рад» тощо) від 11 липня 2002 p. 


\section{Висновок}

Систематизація муніципального законодавства України - це форма його вдосконалення, яка може мати нормотворчий або ненормотворчий характер. Нормотворчий характер притаманний консолідації та кодифікації муніципального законодавства України, а ненормотворчий характер - інкорпорації муніципального законодавства України На підставі аналізу муніципального законодавства України було сформульовано висновок, що його систематизація здійснюється по відношенню до: а) положень національних нормативно-правових актів (Конституції, законів України та підзаконних актів) шляхом застосування інкорпорації, консолідації та кодифікації; б) положень міжнародних договорів, згода на обов'язковість яких надана Парламентом, - шляхом застосування інкорпорації. Аргументовано відсутність доцільності застосування для систематизації муніципального законодавства України таких їі форм, як облік та звід законів.

\section{Список використаних джерел:}

1. Орзіх М. П. Проект Муніципального кодексу України (огляд за матеріалами обговорення в Одеській національній юридичній академії). Юридичний вісник. 2001. № 2. С. 105-137.

2. Мішина Н.В. Термін «самоорганізація населення» в законодавстві та в доктринальній літературі України. Державне управління: теорія та практика. 2006. № 1. URL: http://www.academy.kiev.ua/ej3/txts / REGIONALNE/04-MISCHINA.pdf.

3. Мішина Н.В. Законопроекти для розвитку локальної демократії в Україні. Юридичний вісник. 2014. № 2. C. 36-40.

4. Можаровська К.В. Щодо сучасного стану муніципального законодавства України. Порівняльно-аналітичне право. 2013. № 2. URL: http://www.pap.in.ua/2 2013/Mozharovska.pdf.

5. Можаровська К.В. Закон «Про місцеве самоврядування в Україні» як кодифікований акт. Порівняльно-аналітичне право. 2013. № 3-2.

6. Можаровська К.В. Муніципальний кодекс України: за чи проти? Право і суспільство. 2015. № 2. C. $33-38$.

В статье сформулировано, что систематизация муниципального законодательства Украинььэто форма его усовершенствования, которая может иметь нормотворческий или ненормотворческий характер. Нормотворческий характер присущ, консолидации и кодификации муниципального законодательства Украины, а ненормотворческий характер - инкорпорачии муниципального законодательства Украины. На основании анализа мунииипального законодательства Украины был сформулирован вывод о том, ито его систематизаиия осуществляется в отношении: а) положений наииональных нормативно-правовых актов (Конституиии, законов Украины и подзаконных актов) - путем применения инкорпоращии, консолидации и кодификации; б) положений международных договоров, согласие на обязательность которых дано парламентом, - путем применения инкорпорации. Аргументирована нецелесообразность применения при систематизации муниципального законодательства Украины таких ее форм, как учет и свод законов.

Ключевые слова: муниципальное законодательство, систематизация, классификация муниципального законодательства, кодификация, консолидация, инкорпорация.

The article states that the Ukrainian municipal legislation's systematization is a form of its improvement, which may have normative or non-normative character. The normative character is inherent in the consolidation and codification of the Ukrainian municipal legislation, and the non-normative character v in Ukrainian municipal legislation's incorporation. Based on the analysis of the Ukrainian municipal legislation, it was concluded that its systematization is carried out in relation to: a) the provisions of national legal acts (the Constitution, lawes of Ukraine and by-lawes) - by applying incorporation, consolidation and codification; b) the provisions of international treaties, the consent of which is binding on the Parliament, - by the application of incorporation. It is argued that there is no expediency in applying to systematize the Ukrainian municipal legislation such forms as the accounting and a set of lawes.

Key words: municipal legislation, systematization, systematization of municipal legislation, codification, consolidation, incorporation. 